\title{
Everyday interactions and political participation of Malaysian youth
}

\author{
Su-Hie Ting (D) and Sharifah Sophia Wan Ahmad \\ Universiti Malaysia Sarawak, Sarawak, Malaysia
}

\begin{abstract}
Some scholars have argued that youth apathy in politics arises from an interpretation based on conventional electoral politics. Other scholars have studied unconventional political participation and found the willingness of youth to sign petitions, join boycotts, and attend demonstrations. However, little is known about the potential of everyday interactions to generate youth interest in politics. This study examined youth participation in politics, including everyday interactions, before the 14th general election in Malaysia which changed the ruling government after six decades. Semi-structured interviews were conducted with 28 participants aged 15-40 from lower socio-economic backgrounds. Analysis revealed low levels of political participation in electoral politics. Less than half of them voted in campus elections, and state or parliamentary elections, or attended campaign rallies. None of them were candidates in campus elections, and none of their immediate family members were political candidates. A majority of the participants were engaged in everyday interactions through online news, occasional political conversations with friends, teachers, lecturers and parents, membership in organisations, and writing letters to government agencies. The findings suggest that youth disengagement from politics is due to a closed political climate, and the perception of politics as dirty and for the self-gain of politicians.
\end{abstract}

\author{
ARTICLE HISTORY \\ Received 23 August 2019 \\ Accepted 25 April 2021
}

\section{KEYWORDS}

Political behaviour; electoral politics; unconventional political participation; everyday interaction; youth

\section{Introduction}

The World Health Organization (WHO) and the United Nations (UN) define young people as persons aged between 10 and 24 (adolescents, 10-19; youth, 15-24) (WHO 2020; UN 2020). Despite the United Nations driving the youth agenda on the mainstream political process through its Department of Economic and Social Affairs, studies across nationstates indicated low youth participation in politics. In Latin America, youth interest in electoral and party politics has steadily declined (Coe and Vandegrift 2015). In Norway, the voting rate for first-time voters was a mere $57 \%$ in the 2009 general election (Børhaug 2011). A 2007 survey in Turkey showed that only 9\% of their youth were concerned with politics (Gümüs and Yılmaz 2015). Six years after the youth's self-reported claim of

CONTACT Su-Hie Ting suhieting@gmail.com @ Universiti Malaysia Sarawak, Kota Samarahan, 94300 Sarawak, Malaysia

(4) Supplemental data for this article can be accessed at https://doi.org/10.1080/13676261.2021.1923672 